\title{
Integrating CRISPR Engineering and hiPSC-Derived 2D Disease Modeling Systems
}

\author{
ㅈristina Rehbach, ${ }^{1,2}$ Michael B. Fernando, ${ }^{2,3,4}$ and $\bigodot^{-K r i s t e n ~ J . ~ B r e n n a n d ~}{ }^{1,2,4,5,6}$ \\ ${ }^{1}$ Department of Genetics and Genomics, ${ }^{2}$ Friedman Brain Institute, ${ }^{3}$ Graduate School of Biomedical Science, ${ }^{4}$ Nash Family Department of Neuroscience, \\ ${ }^{5}$ Icahn Institute of Genomics and Multiscale Biology, and ${ }^{6}$ Department of Psychiatry, Icahn School of Medicine at Mount Sinai, New York, New York 10029
}

Human induced pluripotent stem cells (hiPSCs) have revolutionized research on human diseases, particularly neurodegenerative and psychiatric disorders, making it possible to study mechanisms of disease risk and initiation in otherwise inaccessible patient-specific cells. Today, the integration of CRISPR engineering approaches with hiPSC-based models permits precise isogenic comparisons of human neurons and glia. This review is intended as a guideline for neuroscientists and clinicians interested in translating their research to hiPSC-based studies. It offers state-of-the-art approaches to tackling the challenges that are unique to human in vitro disease models, particularly interdonor and intradonor variability, and limitations in neuronal maturity and circuit complexity. Finally, we provide a detailed overview of the immense possibilities the field has to offer, highlighting efficient neural differentiation and induction strategies for the major brain cell types and providing perspective into integrating CRISPR-based methods into study design. The combination of hiPSC-based disease modeling, CRISPR technology, and high-throughput approaches promises to advance our scientific knowledge and accelerate progress in drug discovery.

Key words: Human induced pluripotent stem cells; CRISPR; psychiatric genetics; differentiation; induction; disease modeling

\section{Introduction}

The ability to apply human induced pluripotent stem cells (hiPSCs) to generate, and Clustered Regularly Interspaced Short Palindromic Repeats (CRISPR) engineering to manipulate, a multitude of cell types from either patients or controls has transformed our ability to model human diseases and to probe the mechanisms underlying disease. Genetically engineered rodents have played a critical role in understanding the relationship between genotype, circuit function, and behavior. For genes conserved between humans and rodents, these genotype-phenotype relationships frequently well inform human studies. However, rodent models struggle to recapitulate complex genetic disorders arising from the interactions of dozens of risk variants, particularly when human-specific disease-associated variants or their regulation are not well conserved between species. Moreover, strain-specific genotype-phenotype effects observed in rodent studies highlight the need to study mutations and variants in the context of diverse genetic backgrounds (Sittig et al., 2016). Donor-dependent and human-specific regulatory processes and cellular functions are at least partially to blame for observed vari-

\footnotetext{
Received March 6, 2019; revised 0ct. 23, 2019; accepted 0ct. 23, 2019.

This work was supported in part by National Institute of Mental Health grants R56MH101454 and R01MH106056.

The authors declare no competing financial interests.

Correspondence should be addressed to Kristen J. Brennand at kristen.brennand@mssm.edu.

https://doi.org/10.1523/JNEUROSCI.0518-19.2019

Copyright $\odot 2020$ the authors
}

ability and the failure of promising treatments developed in animal models to show efficacy in humans. Therefore, there is a clear need to study human diseases in human models derived from diverse genetic backgrounds.

Today, a combination of hiPSCs and CRISPR editing of disease-associated variants enables the functional evaluation of genetic risk in diverse genetic contexts, toward understanding the effect of genomic variability across a population. Even for complex genetic disorders, such as schizophrenia (Brennand et al., 2011), bipolar disorder (Mertens et al., 2015a), and autism spectrum disorder (Marchetto et al., 2010; Mariani et al., 2015), developmental phenotypes and drug treatment responses can be modeled in vitro (Silva and Haggarty, 2019).

Overall, hiPSCs are remarkable tools that enable us to move toward precision medicine, while at the same time challenging our basic assumptions about how to best design in vitro experiments. Considering the genetic heterogeneity among individuals (both patients and controls), the variable penetrance of many rare disease-causing variants, and the small effect sizes of common variants associated with brain disease (for review, see Sullivan and Geschwind, 2019), a rigorous hiPSC-based study requires thoughtful consideration of cohort size, donor (case and control) selection, and patient stratification to reduce experimental variability. Although most studies to date have been conducted in one cell type in isolation, there is a growing need to functionally combine diverse neuronal (e.g., glutamatergic, GABAergic, and 


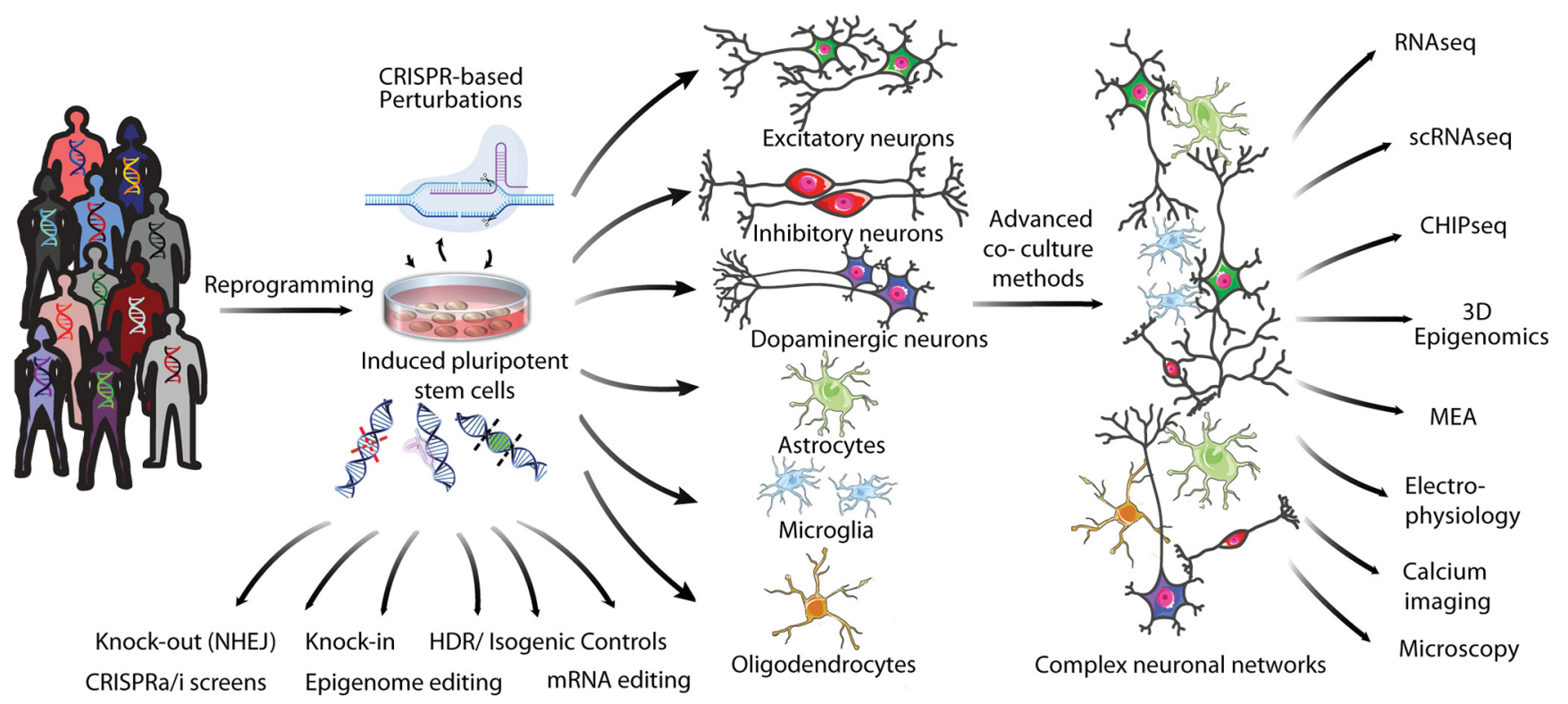

Figure 1. Approaching hiPSC disease modeling. The general human population exhibits high genetic variability, which can be overcome by stratification of the cohort or by CRISPR editing approaches. Generated iPSC lines can be differentiated or induced into several neural cell types, comprising neurons and glia, which can be modularly combined into cocultures for complex genetic, phenotypic, or functional analysis. Components of schematic were adapted from Servier Medical Art (https://smart.servier.com/\#) and BioRender (created with www.BioRender.com).

dopaminergic neurons) and glial (astrocytes, oligodendrocytes, and microglia) cell types into defined "circuits," to model the complex interactions underlying, for example, neuropsychiatric diseases (Figure 1). Ultimately, hiPSCs-derived neurons and glia represent an important source of cells for future drug screening and cell replacement therapies. Here we provide an introduction to hiPSC-based modeling, noting not just the potentials of this approach, but also pointing out potential pitfalls, and striving to provide guidelines for designing these studies in a meaningful way. By applying CRISPR editing to hiPSCs from diverse human genetic backgrounds, and state-of-the-art methods to generate specific neural cell types, hiPSCs represent a new model enabling the study of gene function and disease variants in a humanspecific context. Furthermore, hiPSCs serve as a nearly limitless source of cells for personalized drug screening and cell replacement therapies.

\section{Advantages of hiPSC-based disease models}

Perhaps the greatest advantage of hiPSC-based disease models is the ability to generate and manipulate otherwise inaccessible cell types for the study of human neurodegenerative and psychiatric disorders. The earliest of such studies focused on disorders likely involving single genes, such as Rett syndrome (MECP2) (Marchetto et al., 2010), autism spectrum disorder (SHANK3) (Kathuria et al., 2018), and schizophrenia (DISC1) (Z. Wen et al., 2014; Srikanth et al., 2015). Among other phenotypes, these studies reported fewer synapses in patient-derived neurons, providing strong proof-of-concept evidence that hiPSC-based studies could identify disease phenotypes that were reproducible across cohorts and laboratories.

Because hiPSCs enable researchers to examine the impact of rare and common genetic variants across distinct genetic backgrounds, they are extremely well suited for modeling complex genetic disorders. Due to the differences in penetrance and effect size between risk loci, the most appropriate experimental strategies vary between genetic variants. Although the clinical impact of rare variants can be pleiotropic, rare variants tend to be associated with larger effect sizes, which are thought to be easier to resolve in vitro than common variants with often small effects or incomplete penetrance. There are several examples for the modeling of rare variants: an engineered conditional heterozygous truncation of neurexin1 (NRXN1, associated with SZ, autism, and Pitt-Hopkins-like syndrome 2), in hiPSC-derived neurons led to reduced synaptic transmission (Pak et al., 2015), and C9orf72 (associated with ALS and FTD; patient-derived motor neurons showed evidence of neurodegeneration) (X. Wen et al., 2014; Shi et al., 2018). Identifying and recruiting a sufficient number of patients with rare penetrant variants can be difficult, but variants can now be introduced by CRISPR editing (Tai et al., 2016), making it possible to test their penetrance across different genetic backgrounds.

Studies of common variants have been informed by genomewide association studies (GWAS) of single nucleotide polymorphisms (SNPs), which have identified hundreds of common variants of small effect that are associated with schizophrenia (Schizophrenia Working Group of the Psychiatric Genomics Consortium, 2014; Pardiñas et al., 2018) and other neuropsychiatric disorders. Several studies have used hiPSCs to explore the impact of GWAS-significant loci within patient cohorts (e.g., the involvement of the complement component 4 locus in synaptic elimination) (Sellgren et al., 2017, 2019), but the effect of common variants can also be directly evaluated by applying CRISPR editing to introduce the precise $\mathrm{SNP}(\mathrm{s})$ identified through GWAS. Functional validation can demonstrate whether SNPs play a causal role in gene regulation through, for example: alterations in enhancer-promoter looping, as shown for CACNA1C (Roussos et al., 2014); 3D-genome folding, as shown for $P C D H \alpha$ (Rajarajan et al., 2018); or miRNA levels, as shown for miR-137 (Forrest et al., 2017) and FURIN (Schrode et al., 2019).

Environmental factors with clear biological effectors are also amenable to in vitro study in hiPSC-derived cells. One such example is congenital Zika syndrome; hiPSC-based models were among the first to reveal that neural progenitor cells were the most susceptible to Zika-mediated cell death (Tang et al., 2016) and that infection was mediated by infiltrating microglia (Muffat et al., 2018). Furthermore, hiPSC Zika models were used to 
screen for novel drugs that could prevent infection and promote neural survival (Zhou et al., 2017). Indeed, even the clinical discordance between affected and unaffected dizygotic twins could be recapitulated in vitro following Zika infection of patientderived neural progenitor cells (Caires-Júnior et al., 2018).

One of the most immediate clinical applications of hiPSCderived cells will occur through drug screening (for review, see Moffat et al., 2017). Already, hiPSC-based drug screening has led to the discovery of novel compounds that reduce endogenous human tau (relevant for Alzheimer's disease) (Wang et al., 2017; van der Kant et al., 2019) and confirmed the functionality of drugs identified in mouse models in a human context (Yang et al., 2013). We recently described a proof-of-concept application of transcriptomic drug screening to schizophrenia, wherein we demonstrated cell-type-specific and donor-dependent drug-induced gene expression changes (Readhead et al., 2018).

The full promise of hiPSC-based models lies in the possibility of patient-specific drug screening, the ability to predict clinical treatment response in vitro. The extent to which clinical drug responsiveness is heritable and/or stable throughout the lifetime across the spectrum of neuropsychiatric disease needs further investigation, but promising examples have been reported. For instance, the lithium response of hiPSC-derived neurons from known lithium responders and nonresponders differed in vitro (Mertens et al., 2015a), and clinical lithium response could be accurately predicted by examining as few as five patient-derived neurons (Stern et al., 2018).

In addition, hiPSCs represent the possibility of donor-specific cells for transplantation into patients with neurodegenerative diseases. However, the utility of cell replacement therapy is likely limited to a narrow subset of diseases defined by the loss of a single cell type that is well characterized, surgically accessible, and capable of being generated at high-purity in vitro. Nonetheless, the first clinical trials for retinal disease (Mandai et al., 2017) and Parkinson's disease (Barker et al., 2017) are now underway (for review, see Barker et al., 2018). In either case, being able to conduct drug screens or transplantation therapies using patientmatched cells promises to make possible a move toward precision medicine.

\section{Disadvantages of hiPSC-based disease models}

Studying hiPSC-derived neurons has tremendous benefits and advantages for studying disease; however, their very nature raises challenges and limitations to their use, and these clear disadvantages have to be considered when approaching hiPSC studies. The limited sample size that can yet be achieved is one critical disadvantage of hiPSC-based studies, relative to genetic and postmortem studies. During the reprogramming process, epigenetic marks are mostly removed and somatic cells are reverted to an embryonic-like state. To ensure the generation of a reliable hiPSC line, extensive validation is needed, including confirmation of differentiation potential, absence of residual reprogramming factor expression, and exclusion of additional mutations (Schlaeger et al., 2015). The generation and validation of hiPSCs are timeconsuming and expensive, limiting sample size. We hope that automation (Kiskinis et al., 2014; Paull et al., 2015) and stem cell banking initiatives (https://www.nimhgenetics.org/; https://www. cirm.ca.gov/researchers/ipsc-repository; http://hpscreg.eu) will overcome this obstacle, enabling multiple laboratories to share hiPSCs for comparative studies, reducing costs, and increasing scientific fidelity and possible sample size.

Another difficulty with hiPSC studies is that a perhaps unexpected level of variability occurs between and within donors, re- flecting variation in genetic background coupled with stochastic differences during the reprogramming and neuronal differentiation protocols (Hoffman et al., 2017), limiting resolution of genetically regulated donor effects. Interdonor variation can be well countered by the application of CRISPR-mediated genetic (for review, see Adli, 2018) and/or epigenetic (for review, see Pulecio et al., 2017) perturbations, resulting in isogenic pairs (same genetic background with or without the perturbation) with which to functionally validate the impact of specific disease-associated loci.

Finally, the physiological relevance of hiPSC-derived neuronal populations can be limited by functional immaturity, a failure to form complex neuronal circuits, and lack of myelination and microglia pruning. hiPSC-derived neural cells most resemble fetal counterparts (Nicholas et al., 2013; Brennand et al., 2015), suggesting that they are most appropriate for modeling disease risk rather than end-stage disease processes. While mechanistic studies and drug-based screening in hiPSC-based studies may be better suited to identify drug targets that prevent disease, this offers the possibility of an earlier window for therapeutic intervention. One attempt to improve maturity is the establishment of multicellular systems enabling functional interactions (e.g., myelinating oligodendrocytes) (Douvaras et al., 2014), neuromuscular junctions (Puttonen et al., 2015), and synaptic pruning (Sellgren et al., 2019), even though these systems still lack the maturity and stability of their in vivo counterparts. Ongoing work to advance 3D organoids (Amin and Pasca, 2018; companion Dual Perspectives article), promises to improve the maturity, functionality, and fidelity of hiPSC-based models by incorporating functional vasculature (Mansour et al., 2018), myelination (Madhavan et al., 2018), blood-brain barriers (Vatine et al., 2017), and increasing the diversity of neuronal cell types (Xiang et al., 2017, 2019; Sloan et al., 2018). Interactions among cell types (e.g., cocultures or organoids) are now being explored in higher throughput drug screens (for review, see Miranda et al., 2018).

Although hiPSC-based disease models can be limited by small sample sizes, high interdonor and intradonor variability, lack of maturation, and the limited circuit complexity yet attainable, they represent a path to more accurate modeling of humanspecific disorders and identification of novel therapeutic targets and drugs. hiPSCs offer us the unique opportunity to study human diseases using patient-derived cells. When coupled with CRISPR engineering, they provide the ability to model and manipulate risk factors linked to both monogenic and complex genetic disorders, and the heterogeneity between cases (and controls) allows us to explore the effect of variable penetrance and genetic background.

\section{Major considerations in study design}

Although hiPSCs are a powerful tool to unravel phenotypes and mechanisms of human diseases, to achieve meaningful results and statistical resolution, cohort size, patient stratification, and suitable cell types must be carefully considered. For example, complex diseases can be modeled by reprogramming patientderived samples or by engineering specific disease-associated variant(s). For the former, a larger cohort consisting of multiple patients and controls is needed, necessitating stratification of patients and controls selected based on shared genetic, clinical, or pharmaceutical response traits. For the latter, one must choose to either introduce a disease-associated variant in a control donor background or reverse it in a patient-derived hiPSC, with potential issues of penetrance and unknown epistatic interactions in either case. 
Achieving statistical significance in phenotypic comparisons is frequently problematic for one of two reasons: (1) limited experimental size owing to the time-consuming and expensive nature of these studies and (2) increased experimental noise arising from both interdonor variability in genetic background and intradonor stochastic heterogeneity in cell type composition between experimental replicates. Nonetheless, with thoughtful experimental design with respect to cohort size, donor selection, cell type(s) of interest, and phenotypic assay(s), both case-control and hiPSC-based studies yield novel insights into disease and drug response.

\section{What size of cohort is large enough?}

Given the genetic heterogeneity within patient and control populations, it is important to consider the size of case-control studies (i.e., the number of patients and healthy controls to enroll and the number of hiPSC lines to characterize per donor) and the number of independent genetic backgrounds across which CRISPR-based isogenic comparisons should be conducted.

Reprogramming, differentiation, and phenotypic analyses of hiPSC-derived neural cells can be cumbersome, time-consuming, and expensive. One reprogramming experiment produces several clones per donor, which are very similar and carry in principle the same genetic background; however, preexisting somatic mutations or alterations during the reprogramming process can lead to slight variations between clones. When studying idiopathic disease, genetic analyses have increasingly revealed that, given the costs involved, it is always preferable to add additional independent donors rather than duplicate hiPSC clones per donor, due to the limited knowledge about variation in idiopathic diseases (Hoffman et al., 2017). For rare variant studies, where the number of available patients is limiting, increased statistical power can be acquired by generating multiple hiPSCs per donor. Recent idiopathic hiPSC cohorts have reached $\sim 10$ cases and 10 controls, with multiple hiPSC clones per donor (Topol et al., 2016; Hoffman et al., 2017; Lang et al., 2019), while studies of isogenic pairs typically use just one or two donor backgrounds for editing (Yi et al., 2016; Forrest et al., 2017; Kiskinis et al., 2018). The largest hiPSC cohorts (711 hiPSC lines from 301 individuals) have been applied to expression quantitative trait loci analyses, linking genomic SNP data to expression data of a specific locus, revealing that up to $50 \%$ of variability arises from different genetic backgrounds (Carcamo-Orive et al., 2017; DeBoever et al., 2017; Kilpinen et al., 2017). With current methodologies, hiPSCbased recall-by-genotype studies, which recruit patients on the basis of genetic variation, require at least $20-80$ donors to detect the effects of regulatory variants (Schwartzentruber et al., 2018).

Overall, both attaining an appropriate cohort size to achieve statistical significance and incorporating isogenic comparisons are crucial for making biologically meaningful conclusions. Although recent papers have described relatively small sample sizes across which molecular and cellular readouts have been possible, current thinking is that cohort size should always be maximized, even at the expense of replicated hiPSC clones from each donor (Germain and Testa, 2017; Hoffman et al., 2017).

\section{Which patients should be recruited?}

Given the substantial costs associated with generating a large case-control hiPSC cohort, it is important that one carefully consider issues associated with accurate diagnosis, patient stratification, and appropriately matched controls, together with the inclusion of isogenic comparisons.

Because a single clinical designation can apply to a collection of phenotypes resulting from distinct genetic perturbations (e.g., influenced by the affected gene, genetic region, expression signature, polygenic risk score), genetic stratification can improve study design by focusing on shared underlying mechanisms. One must strive to carefully select representative and meaningful donors, given the limited samples sizes currently possible with hiPSC-based disease models. This can either be based on matching the underlying genetic cause, or if unknown, on shared clinical (e.g., imaging, ENIGMA; http://enigma.ini.usc.edu/) (Thompson et al., 2014), pharmacological (e.g., drug responsiveness) (Stern et al., 2018), or genetic information (e.g., polygenic risk score) (for review, see Hoekstra et al., 2017; Hoffman et al., 2019) of donors.

Another useful design is to specifically recruit or CRISPR-edit donor-specific cells to assess the impact of variable penetrance across genetic backgrounds. For example, carriers of the APOE4/4 risk variant are substantially more susceptible to Alzheimer's disease than APOE3/3 carriers (Lin et al., 2018); a cohort comprised of APOE $4 / 4$ resilient controls and Alzheimer's disease cases could inform on the biological pathways limiting disease progression. An example of selection based on clinical presentation is NRXN1, where copy number variations are strongly associated with both autism spectrum disorder and schizophrenia (Matsunami et al., 2013; Marshall et al., 2017).

As an alternative to case-control design, rare or common variants identified by GWAS can either be introduced into control hiPSCs or repaired in patient hiPSCs. For rare variants, the precise mutation to be engineered is generally straightforward to identify; with common variants, selection is much more nuanced. First, putative causal common variant SNPs can be inferred by demonstrating that they are associated with gene expression in the cell type(s) relevant to disease. For example, by directly integrating schizophrenia-associated GWAS SNPs to those linked to gene regulation in the postmortem brain, diseaseassociated common variant risk loci associated with both gene expression and disease liability could be identified (Fromer et al., 2016). Second, although SNPs are frequently inherited together via linkage disequilibrium, linkage disequilibrium blocks can sometimes be resolved to a single putative causal SNP via fine-mapping analyses (Dobbyn et al., 2018). Depending on the number of putative causal SNPs identified at a given loci (and their hypothesized mechanism of action), a variety of CRISPR-based tools are available to enable isogenic comparisons.

In summary, the design of an ideal hiPSC cohort for disease modeling should be based on accurate diagnosis, which can be further refined by genetic characterization and/or clinical patient stratification. An alternative approach is the targeted genome engineering of known variants or risk factors.

\section{Who is the ideal "control?"}

The generation of isogenic controls (i.e., the introduction or repair of a disease-associated mutation) allows the comparative analysis of variants in the same donor background, vastly reducing variability confounded by difference in genomic background. Furthermore, CRISPR editing can facilitate the study of penetrance of risk variants across genetic backgrounds (e.g., a high or low polygenic risk score for disease) and can be particularly valuable when no patient material is available. To evaluate penetrance, isogenic studies can be conducted across different genetic backgrounds from donors with high and low polygenic disease risk scores. At the same time, potential additive effects of additional variants can be directly tested, to explore the molecular and functional convergence of risk factors. 
Table 1. Overview of 2D differentiation and induction protocols of neural cell types from hiPSCs, including timing, efficiency, and induction factors

\begin{tabular}{|c|c|c|c|c|c|}
\hline \multirow[t]{2}{*}{ Cell type } & \multicolumn{2}{|l|}{ Differentiation } & \multicolumn{3}{|l|}{ Induction } \\
\hline & Timing & Efficiency & Factors & Timing & Efficiency \\
\hline \multirow[t]{2}{*}{ Glutamatergic neurons } & $80 d$ & \multirow[t]{2}{*}{$80 \%-100 \%$} & NGN2 & \multirow[t]{2}{*}{$<2$ weeks } & \multirow[t]{2}{*}{$\sim 100 \%$} \\
\hline & Shi et al. 2012 & & Zhang et al., 2013 & & \\
\hline \multirow[t]{2}{*}{ GABAergic neurons } & 6 weeks & \multirow[t]{2}{*}{$>95 \%$} & $D L X 2, A S C L 1$ & \multirow[t]{2}{*}{4 weeks } & \multirow[t]{2}{*}{$>80 \%$} \\
\hline & Liu et al., 2013; Maroof et al., 2013 & & Sun et al., 2016; Yang et al., 2017 & & \\
\hline \multirow[t]{2}{*}{ Dopaminergic neurons } & $35 d$ & \multirow[t]{2}{*}{$90 \%$} & ASCL1, NURR1, LMX1A & \multirow[t]{2}{*}{$21 d$} & \multirow[t]{2}{*}{$>93 \%$} \\
\hline & Kriks et al., 2011; Zhang et al., 2014 & & Caiazzo et al., 2011; Theka et al., 2013 & & \\
\hline \multirow[t]{2}{*}{ Serotonergic neurons } & 6 weeks & \multirow[t]{2}{*}{$60 \%$} & NKX2.2, FEV, GATA2, LMX1B, ASCL1, NGN2 & \multirow[t]{2}{*}{3 weeks from fibroblasts } & \multirow[t]{2}{*}{$60 \%$} \\
\hline & Lu et al., 2016 & & Vadodaria et al., 2016 & & \\
\hline \multirow[t]{2}{*}{ Motor neurons } & 4 weeks & \multirow[t]{2}{*}{$\sim 90 \%$} & LHX3, NGN2, ISL1 & \multirow[t]{2}{*}{2 weeks } & \multirow[t]{2}{*}{$\sim 85 \%$} \\
\hline & Du et al., 2015 & & Goto et al., 2017 & & \\
\hline \multirow[t]{2}{*}{ Astrocytes } & $<30 \mathrm{~d}$ & \multirow[t]{2}{*}{$90 \%$} & SOX9, NFIB & \multirow[t]{2}{*}{2 weeks } & \multirow[t]{2}{*}{$96 \%$} \\
\hline & TCW et al., 2017 & & Canals et al., 2018 & & \\
\hline \multirow[t]{4}{*}{ Oligodendrocytes } & $75 d$ & \multirow[t]{4}{*}{$45 \%-70 \%$} & SOX10 and OLIG2 & \multirow[t]{3}{*}{$20 d$} & almost \\
\hline & Wang et al., 2013; Douvaras et al., 2014; & & Pawlowski et al., 2017 & & $100 \%$ \\
\hline & Douvaras and Fossati, 2015 & & SOX10, 0LIG2, NKX60.2 & & \\
\hline & & & Ehrlich et al., 2017 & $28 d$ & $60-70 \%$ \\
\hline \multirow[t]{2}{*}{ Microglia } & 5 weeks & \multirow[t]{2}{*}{$>90 \%$} & - & \multirow[t]{2}{*}{-} & \multirow[t]{2}{*}{-} \\
\hline & Muffat et al., 2016; Abud et al., 2017 & & & & \\
\hline
\end{tabular}

When isogenic comparisons are not possible, unaffected relatives or age- and sex-matched controls are typically used as a point of comparison. Unfortunately, there is often little known about healthy donors, and there is usually no possibility to track disease state after the time of donation, leaving uncertainty about whether the young "healthy donor" will remain healthy. Old donors provide the advantage of a known clinical history, but the disadvantage of a lifetime of possible accumulation of somatic mutations that might be present in donor hiPSCs and could influence gene expression and phenotypes of hiPSC-derived cells (Lo Sardo et al., 2017). Thus, we should probably be acquiring donor material as part of longitudinal studies, ultimately yielding hiPSCs derived from old, healthy donors that were generated in their younger years and frozen as somatic cells or hiPSCs for future studies.

In summary, when developing hiPSC-based disease models, it is crucial to choose an appropriate cohort size and to incorporate the recruitment and/or isogenic editing of suitable controls. In addition, it is beneficial to focus on genetically characterized patients sharing common risk factors. By integrating hiPSC-based approaches with CRISPR engineering, in vitro studies can explore the impact of disease-associated risk factors across a range of genetic backgrounds, which may help us to improve geneticbased diagnosis, prognosis, and treatment.

\section{Which cell types should be studied?}

Because neurological diseases often stem from effects on specific cell types, it is crucial to consider the impact of disease-associated variants within and between the diverse cell types that make up the brain. Which cell type(s) to study for a given disease might be answered by relying on clinical data, imaging studies, animal studies, and publicly available expression data of in vivo and hiPSC-derived cells (e.g., www.brainrnaseq.org; http://cortecon. neuralsci.org/), to determine which cell types express the gene of interest or are affected by disease.

Advances in directed differentiation protocols largely reflect an improved understanding of, and ability to recapitulate, the growth factors and regionalization factors present during neurodevelopment. To date, efficient differentiation protocols for most of the major neural cell types, including cortical neurons, dopaminergic neurons, astrocytes, oligodendrocytes, and microglia have been established and validated across multiple sites (Schwartzentruber et al., 2018). Using these classical differentiation protocols, the purity of differentiated neural cell populations can reach $80 \%$; however, extensive variability can occur between hiPSC lines of different genetic backgrounds, both in the yield of the desired cell type and in the composition of the undesired cells (Hoffman et al., 2017).

Extrinsic growth factors applied during the course of these differentiation protocols ultimately result in changes in signaling and transcription factor activity within the differentiating cells. Identifying the key transcription factors regulating specific neural fates, either through screening of candidates (Vierbuchen et al., 2010; Pang et al., 2011) or unbiased genomewide screening (Liu et al., 2018; Tsunemoto et al., 2018), enables the direct induction of neural fate by overexpression of critical transcription factors. Today, several protocols are widely used: for example, overexpression of NGN2 rapidly generates a nearly pure neuronal population with glutamatergic forebrain identity (Zhang et al., 2013; Ho et al., 2016), whereas overexpression of DLX2 and ASCL1 produces GABAergic neurons (Sun et al., 2016; Yang et al., 2017).

A comprehensive overview of some of the most reliable differentiation and induction protocols for the major neural cell types is provided in Table 1, including a comparison of the yields and timelines. Although classical differentiations can achieve enriched cultures, as noted above, they often produce impure, mixed populations of different cell types with varying compositions and maturities over more protracted time courses. Advanced transcription factor induction-based protocols, on the other hand, generate cell types at higher purities, effectively reducing the variability within and between experiments. This higher purity enables the assembly of more complex, defined populations with known cell-type compositions to study cell- 
type interactions. Another advantage of induced neurons is an accelerated functional maturation, achieving electrophysiological maturity at earlier time points than their classically differentiated counterparts (Meijer et al., 2019; Rhee et al., 2019).

Nonetheless, neurons differentiated and induced from hiPSCs most resemble fetal cells (Nicholas et al., 2013; Brennand et al., 2015), whereas neurons directly induced from aged somatic fibroblasts maintain aged markers (Pang et al., 2011; Mertens et al., 2015b), suggesting that the choice of neural generation methods might reflect whether the experimental objective is to query development, disease risk, or later aspects of disease state.

In contrast to $2 \mathrm{D}$ differentiation or induction methods, 3D organoids techniques generate a self-organizing brain-like structure containing several different cell types (see companion Dual Perspectives article; Li et al. 2020). While these models reflect improved cellular complexity and are valuable for studying selforganization, migration, and certain aspects of brain architecture, they often display a high degree of variability between donors and experiments (Quadrato et al., 2017; de Souza, 2018), limiting their potential for studying small effect sizes or defined cell types and compositions. More recent protocols achieve higher reproducibility between organoids and experiments (Velasco et al., 2019), and 3D culture makes it possible to use extended differentiation protocols (up to 1 year), facilitating maturation in organoid cultures (Pasca et al., 2015). Overall, by developing a toolbox of methods by which to generate a growing number of cell types in $2 \mathrm{D}$, our collective ability to generate more complex "circuits" is being advanced.

The necessity for modeling the interactions between different cell types is exemplified by schizophrenia, where the genetic data strongly point to an enrichment of genetic risk in glutamatergic and different subsets of GABAergic neurons (Skene et al., 2018). hiPSC-based schizophrenia models have not only reported deficits in glutamatergic neurons (Yu et al., 2014) and GABAergic neurons (Shao et al., 2019), but also neural progenitor cells (Brennand et al., 2015), dopaminergic neurons (Hook et al., 2014), astrocytes (Windrem et al., 2017), oligodendrocytes (McPhie et al., 2018), and microglia (Sellgren et al., 2019). There are consistent difficulties in resolving the primary cell type underlying disease and the complex interactions of cell types that produce clinical phenotypes, which may be better addressed using defined coculture populations.

Ultimately, the ability to separate cell-type-specific signatures from these complex populations, by single-cell analyses (Skene et al., 2018; Lang et al., 2019), FACS-based physical separation (Arlotta et al., 2005), biochemical ribosome-tagged separations (Sanz et al., 2009; Lesiak and Neumaier, 2016), and/or computational strategies (for review, see Avila Cobos et al., 2018), will allow the deconvolution of cell-type-specific effects, alone and in coculture with other cell types.

Overall, a variety of protocols for the generation of distinct subtypes of neurons and glia have now been reported, using both differentiation and induction approaches. By developing an expanded set of methodologies by which to generate increasingly defined neural cell types, we are progressively able to construct cocultures of more advanced and complex neuronal models to tackle underlying mechanisms and interactions in disease relevant readouts.

\section{Assays for resolving disease-relevant insights}

Experimental readouts can comprise a variety of unbiased omics (transcriptomics, epigenetics, and proteomics) approaches, functional evaluation of populationwide activity and single-cell elec- trophysiology, and/or disease-specific cellular and biochemical assays (Fig. 1). Recent advances, particularly at the single-cell level, have begun to yield remarkable insights linking genotype, gene expression, and function. For example, single-cell RNAseq of hiPSC-derived dopaminergic neurons derived from patients with Parkinson's disease yielded a pseudo-time analysis that temporally ordered differentially expressed genes and prioritized the transcriptional repressor histone deacetylase 4 (HDAC4) as a putative driver gene (Lang et al., 2019). Single-cell electrophysiological analyses can also resolve genotype-associated presynaptic and postsynaptic deficits, particularly when low numbers of disease and control isogenic neurons are "sprinkled" onto a shared neuronal lawn to generate sparse connectivity cultures (Schrode et al., 2019; Zaslavsky et al., 2019). New methods, such as "optopatch," will hopefully yield increased scalability of single-cell recordings of neuronal activity (Kiskinis et al., 2018).

In conclusion, hiPSCs represent a powerful platform with which to observe important biological characteristics and cellular interactions in the context of disease or drug treatment.

\section{Advances in CRISPR-mediated strategies}

Isogenic comparisons reduce the variation introduced by genetic background and enable focused investigation of the impact of one or more variants. Advances and widespread application of CRISPR technology enable rapid manipulation of the genome (e.g., generation of isogenic controls) but also facilitate transient manipulations and changes to the epigenome (for review, see Pulecio et al., 2017; Adli, 2018).

The CRISPR/Cas systems are widely used for efficient KO of genes in a heterozygous and homozygous manner, through indel formation via nonhomologous end joining, homology directed repair, or knock-in (for review, see Powell et al., 2017). To remove or invert larger genomic loci, multiplexing CRISPR approaches can be applied. CRISPR systems function through a catalytic or nuclease null "effector" protein that is guided via a synthetically derived RNA. The Cas9 effector is most prominently used in CRISPR-based applications; however, new effectors, such as Cpf1 identified in different bacterial species, have been adapted to increase editing specificities or broaden targeting ranges (Zetsche et al., 2015; Singh et al., 2018).

CRISPR activation or inhibition (CRISPRa/i) can directly modulate endogenous expression levels of one or more genes, through the recruitment of an additional effector protein by an inactive dCas9 (for review, see Vora et al., 2016). Interestingly, the efficiency of CRISPRa/i can vary by donor and cell type, emphasizing the need to carefully validate the platform for each experiment (Ho et al., 2017). New CRISPR systems (CasRx) can modulate RNA, rather than DNA, making possible the perturbation not just of mRNA levels, but also alternative splicing patterns (Konermann et al., 2018). By coupling incompatible Cas9-, Cpf1-, and CasRx-based CRISPRa/i approaches, bidirectional and combinatorial perturbations should be feasible. For a more permanent modulation that can be passed onto daughter cells, effectors targeting the epigenome (Hilton et al., 2015; Liu et al., 2016) can be used. CRISPR can even be used to modulate and study the 3D genome via CRISPR-GO, redirecting specific loci to nuclear compartments (Wang et al., 2018). Ultimately, unbiased genomewide CRISPR KO, CRISPRa, and/or CRISPRi screens will make the discovery of novel regulators of cell fate, neuronal function, and disease processes possible (Kurata et al., 2018; Sanson et al., 2018; Tian et al., 2019).

In conclusion, hiPSC-derived neural cells are an invaluable tool for the study of human neurodevelopment and neuropsychi- 
atric diseases, enabling the modeling of monogenic as well as complex genetic disorders and interacting biological factors. Incorporating rigorous diagnostic criteria and further patient stratification, as well as isogenic controls, can add further value to disease models. Ultimately, elucidation of the genetic factors underlying disease risk, of the cellular processes of disease initiation, and of the associated pathological mechanisms, offers the possibility to interfere with disease risk before clinical disease onset. Overall, hiPSC-based models represent an important tool with which to advance genetic diagnosis and to optimize drug-screening platforms for drug discovery.

\section{References}

Abud EM, Ramirez RN, Martinez ES, Healy LM, Nguyen CH, Newman SA, Yeromin AV, Scarfone VM, Marsh SE, Fimbres C, Caraway CA, Fote GM, Madany AM, Agrawal A, Kayed R, Gylys KH, Cahalan MD, Cummings BJ, Antel JP, Mortazavi A, et al. (2017) iPSC-derived human microglialike cells to study neurological diseases. Neuron 94:278-293.e9.

Adli M (2018) The CRISPR tool kit for genome editing and beyond. Nat Commun 9:1911.

Amin ND, Pasca SP (2018) Building models of brain disorders with threedimensional organoids. Neuron 100:389-405.

Arlotta P, Molyneaux BJ, Chen J, Inoue J, Kominami R, Macklis JD (2005) Neuronal subtype-specific genes that control corticospinal motor neuron development in vivo. Neuron 45:207-221.

Avila Cobos F, Vandesompele J, Mestdagh P, De Preter K (2018) Computational deconvolution of transcriptomics data from mixed cell populations. Bioinformatics 34:1969-1979.

Barker RA, Parmar M, Studer L, Takahashi J (2017) Human trials of stem cell-derived dopamine neurons for Parkinson's disease: dawn of a new era. Cell Stem Cell 21:569-573.

Barker RA, Götz M, Parmar M (2018) New approaches for brain repair: from rescue to reprogramming. Nature 557:329-334.

Brennand KJ, Simone A, Jou J, Gelboin-Burkhart C, Tran N, Sangar S, Li Y, Mu Y, Chen G, Yu D, McCarthy S, Sebat J, Gage FH (2011) Modelling schizophrenia using human induced pluripotent stem cells. Nature 473: 221-225.

Brennand K, Savas JN, Kim Y, Tran N, Simone A, Hashimoto-Torii K, Beaumont KG, Kim HJ, Topol A, Ladran I, Abdelrahim M, MatikainenAnkney B, Chao SH, Mrksich M, Rakic P, Fang G, Zhang B, Yates JR 3rd, Gage FH (2015) Phenotypic differences in hiPSC NPCs derived from patients with schizophrenia. Mol Psychiatry 20:361-368.

Caiazzo M, Dell'Anno MT, Dvoretskova E, Lazarevic D, Taverna S, Leo D, Sotnikova TD, Menegon A, Roncaglia P, Colciago G, Russo G, Carninci P, Pezzoli G, Gainetdinov RR, Gustincich S, Dityatev A, Broccoli V (2011) Direct generation of functional dopaminergic neurons from mouse and human fibroblasts. Nature 476:224-227.

Caires-Júnior LC, Goulart E, Melo US, Araujo BH, Alvizi L, Soares-Schanoski A, de Oliveira DF, Kobayashi GS, Griesi-Oliveira K, Musso CM, Amaral MS, daSilva LF, Astray RM, Suárez-Patiño SF, Ventini DC, Gomes da Silva S, Yamamoto GL, Ezquina S, Naslavsky MS, Telles-Silva KA, et al. (2018) Discordant congenital Zika syndrome twins show differential in vitro viral susceptibility of neural progenitor cells. Nat Commun 9:475.

Canals I, Ginisty A, Quist E, Timmerman R, Fritze J, Miskinyte G, Monni E, Hansen MG, Hidalgo I, Bryder D, Bengzon J, Ahlenius H (2018) Rapid and efficient induction of functional astrocytes from human pluripotent stem cells. Nat Methods 15:693-696.

Carcamo-Orive I, Hoffman GE, Cundiff P, Beckmann ND, D'Souza SL, Knowles JW, Patel A, Papatsenko D, Abbasi F, Reaven GM, Whalen S, Lee P, Shahbazi M, Henrion MY, Zhu K, Wang S, Roussos P, Schadt EE, Pandey G, Chang R, et al. (2017) Analysis of transcriptional variability in a large human iPSC library reveals genetic and non-genetic determinants of heterogeneity. Cell Stem Cell 20:518-532.e9.

de Souza N (2018) Organoids. Nat Methods 15:23.

DeBoever C, Li H, Jakubosky D, Benaglio P, Reyna J, Olson KM, Huang H, Biggs W, Sandoval E, D’Antonio M, Jepsen K, Matsui H, Arias A, Ren B, Nariai N, Smith EN, D’Antonio-Chronowska A, Farley EK, Frazer KA (2017) Large-scale profiling reveals the influence of genetic variation on gene expression in human induced pluripotent stem cells. Cell Stem Cell 20:533-546.e7.

Dobbyn A, Huckins LM, Boocock J, Sloofman LG, Glicksberg BS, Giambar- tolomei C, Hoffman GE, Perumal TM, Girdhar K, Jiang Y, Raj T, Ruderfer DM, Kramer RS, Pinto D, Pinto D, Akbarian S, Roussos P, Domenici E, Devlin B, Sklar P,et al. (2018) Landscape of conditional eQTL in dorsolateral prefrontal cortex and co-localization with schizophrenia GWAS. Am J Hum Genet 102:1169-1184.

Douvaras P, Fossati V (2015) Generation and isolation of oligodendrocyte progenitor cells from human pluripotent stem cells. Nat Protoc 10:1143-1154.

Douvaras P, Wang J, Zimmer M, Hanchuk S, O'Bara MA, Sadiq S, Sim FJ, Goldman J, Fossati V (2014) Efficient generation of myelinating oligodendrocytes from primary progressive multiple sclerosis patients by induced pluripotent stem cells. Stem Cell Reports 3:250-259.

Du Z, Chen H, Liu H, Lu J, Qian K, Huang C, Zhong X, Fan F, Zhang S (2015) Generation and expansion of highly pure motor neuron progenitors from human pluripotent stem cells. Nat Commun 6:1-9.

Ehrlich M, Mozafari S, Glatza M, Starost L, Velychko S, Hallmann AL, Cui QL, Schambach A, Kim KP, Bachelin C, Marteyn A, Hargus G, Johnson RM, Antel J, Sterneckert J, Zaehres H, Schöler HR, Baron-Van Evercooren A, Kuhlmann T (2017) Rapid and efficient generation of oligodendrocytes from human induced pluripotent stem cells using transcription factors. Proc Natl Acad Sci U S A 114:E2243-E2252.

Forrest MP, Zhang H, Moy W, McGowan H, Leites C, Dionisio LE, Xu Z, Shi J, Sanders AR, Greenleaf WJ, Cowan CA, Pang ZP, Gejman PV, Penzes P, Duan J (2017) Open chromatin profiling in hiPSC-derived neurons prioritizes functional noncoding psychiatric risk variants and highlights neurodevelopmental loci. Cell Stem Cell 21:305-318.e8.

Fromer M, Roussos P, Sieberts SK, Johnson JS, Kavanagh DH, Perumal TM, Ruderfer DM, Oh EC, Topol A, Shah HR, Klei LL, Kramer R, Pinto D, Gümüs ZH, Cicek AE, Dang KK, Browne A, Lu C, Xie L, Readhead B, et al. (2016) Gene expression elucidates functional impact of polygenic risk for schizophrenia. Nat Neurosci 19:1442-1453.

Germain PL, Testa G (2017) Taming human genetic variability: transcriptomic meta-analysis guides the experimental design and interpretation of iPSC-based disease modeling. Stem Cell Reports 8:1784-1796.

Goto K, Imamura K, Komatsu K, Mitani K, Aiba K, Nakatsuji N, Inoue M, Kawata A, Yamashita H, Takahashi R, Inoue H (2017) Simple derivation of spinal motor neurons from ESCs/iPSCs using Sendai virus vectors. Mol Ther Methods Clin Dev 4:115-125.

Hilton IB, D'Ippolito AM, Vockley CM, Thakore PI, Crawford GE, Reddy TE, Gersbach CA (2015) Epigenome editing by a CRISPR-Cas9-based acetyltransferase activates genes from promoters and enhancers. Nat Biotechnol 33:510-517.

Ho SM, Hartley BJ, Tcw J, Beaumont M, Stafford K, Slesinger PA, Brennand KJ (2016) Rapid Ngn2-induction of excitatory neurons from hiPSCderived neural progenitor cells. Methods 101:113-124.

Ho SM, Hartley BJ, Flaherty E, Rajarajan P, Abdelaal R, Obiorah I, Barretto N, Muhammad H, Phatnani HP, Akbarian S, Brennand KJ (2017) Evaluating synthetic activation and repression of neuropsychiatric-related genes in hiPSC-derived NPCs, Neurons, and Astrocytes. Stem Cell Reports 9:615-628.

Hook V, Brennand KJ, Kim Y, Toneff T, Funkelstein L, Lee KC, Ziegler M, Gage FH (2014) Human iPSC neurons display activity-dependent neurotransmitter secretion: aberrant catecholamine levels in schizophrenia neurons. Stem cell reports 3:531-538.

Hoekstra SD, Stringer S, Heine VM, Posthuma D (2017) Geneticallyinformed patient selection for iPSC studies of complex diseases may aid in reducing cellular heterogeneity. Front Cell Neurosci 11:164.

Hoffman GE, Hartley BJ, Flaherty E, Ladran I, Gochman P, Ruderfer DM, Stahl EA, Rapoport J, Sklar P, Brennand KJ (2017) Transcriptional signatures of schizophrenia in hiPSC-derived NPCs and neurons are concordant with post-mortem adult brains. Nat Commun 8:2225.

Hoffman GE, Schrode N, Flaherty E, Brennand KJ (2019) New considerations for hiPSC-based models of neuropsychiatric disorders. Mol Psychiatry 24:49-66.

Kathuria A, Nowosiad P, Jagasia R, Aigner S, Taylor RD, Andreae LC, Gatford NJF, Lucchesi W, Srivastava DP, Price J (2018) Stem cell-derived neurons from autistic individuals with SHANK3 mutation show morphogenetic abnormalities during early development. Mol Psychiatry 23:735746.

Kilpinen H, Goncalves A, Leha A, Afzal V, Alasoo K, Ashford S, Bala S, Bensaddek D, Casale FP, Culley OJ, Danecek P, Faulconbridge A, Harrison PW, Kathuria A, McCarthy D, McCarthy SA, Meleckyte R, Memari Y, 
Moens N, Soares F, et al. (2017) Common genetic variation drives molecular heterogeneity in human iPSCs. Nature 546:370-375.

Kiskinis E, Sandoe J, Williams LA, Boulting GL, Moccia R, Wainger BJ, Han S, Peng T, Thams S, Mikkilineni S, Mellin C, Merkle FT, Davis-Dusenbery BN, Ziller M, Oakley D, Ichida J, Di Costanzo S, Atwater N, Maeder ML, Goodwin MJ, et al. (2014) Pathways disrupted in human ALS motor neurons identified through genetic correction of mutant SOD1. Cell Stem Cell 14:781-795.

Kiskinis E, Kralj JM, Zou P, Weinstein EN, Zhang H, Tsioras K, Wiskow O, Ortega JA, Eggan K, Cohen AE (2018) All-optical electrophysiology for high-throughput functional characterization of a human iPSC-derived motor neuron model of ALS. Stem Cell Reports 10:1991-2004.

Konermann S, Lotfy P, Brideau NJ, Oki J, Shokhirev MN, Hsu PD (2018) Transcriptome engineering with RNA-targeting type VI-D CRISPR effectors. Cell 173:665-676.e14.

Kriks S, Shim JW, Piao J, Ganat YM, Wakeman DR, Xie Z, Carrillo-Reid L, Auyeung G, Antonacci C, Buch A, Yang L, Beal MF, Surmeier DJ, Kordower JH, Tabar V, Studer L (2011) Dopamine neurons derived from human ES cells efficiently engraft in animal models of Parkinson's disease. Nature 480:547-551.

Kurata M, Yamamoto K, Moriarity BS, Kitagawa M, Largaespada DA (2018) CRISPR/Cas9 library screening for drug target discovery. J Hum Genet 63:179-186.

Lang C, Campbell KR, Ryan BJ, Carling P, Attar M, Vowles J, Perestenko OV, Bowden R, Baig F, Kasten M, Hu MT, Cowley SA, Webber C, WadeMartins R (2019) Single-cell sequencing of iPSC-dopamine neurons reconstructs disease progression and identifies HDAC4 as a regulator of Parkinson cell phenotypes. Cell Stem Cell 24:93-106.e6.

Lesiak AJ, Neumaier JF (2016) RiboTag: not lost in translation. Neuropsychopharmacology 41:374-376.

Li Y, Tian A, Muffat J (2020) Studying human neurodevelopment and diseases using $3 \mathrm{D}$ brain organoids. Journal of Neuroscience, in press.

Lin YT, Seo J, Gao F, Feldman HM, Wen HL, Penney J, Cam HP, Gjoneska E, Raja WK, Cheng J, Rueda R, Kritskiy O, Abdurrob F, Peng Z, Milo B, Yu CJ, Elmsaouri S, Dey D, Ko T, Yankner BA, et al. (2018) APOE4 causes widespread molecular and cellular alterations associated with Alzheimer's disease phenotypes in human iPSC-derived brain cell types. Neuron 98: 1141-1154.e7.

Liu J, Li M, Luo XJ, Su B (2018) Systems-level analysis of risk genes reveals the modular nature of schizophrenia. Schizophr Res 201:261-269.

Liu XS, Wu H, Ji X, Stelzer Y, Wu X, Czauderna S, Shu J, Dadon D, Young RA, Jaenisch R (2016) Editing DNA methylation in the mammalian genome. Cell 167:233-247.e17.

Liu Y, Liu H, Sauvey C, Yao L, Zarnowska ED, Zhang SC (2013) Directed differentiation of forebrain GABA interneurons from human pluripotent stem cells. Nat Protoc 8:1670-1679.

Lo Sardo V, Ferguson W, Erikson GA, Topol EJ, Baldwin KK, Torkamani A (2017) Influence of donor age on induced pluripotent stem cells. Nat Biotechnol 35:69-74.

Lu J, Zhong X, Liu H, Hao L, Huang CT, Sherafat MA, Jones J, Ayala M, Li L, Zhang SC (2016) Generation of serotonin neurons from human pluripotent stem cells. Nat Biotechnol 34:89-94.

Madhavan M, Nevin ZS, Shick HE, Garrison E, Clarkson-Paredes C, Karl M, Clayton BL, Factor DC, Allan KC, Barbar L, Jain T, Douvaras P, Fossati V, Miller RH, Tesar PJ (2018) Induction of myelinating oligodendrocytes in human cortical spheroids. Nat Methods 15:700-706.

Mandai M, Watanabe A, Kurimoto Y, Hirami Y, Morinaga C, Daimon T, Fujihara M, Akimaru H, Sakai N, Shibata Y, Terada M, Nomiya Y, Tanishima S, Nakamura M, Kamao H, Sugita S, Onishi A, Ito T, Fujita K, Kawamata S, et al. (2017) Autologous induced stem-cell-derived retinal cells for macular degeneration. N Engl J Med 376:1038-1046.

Mansour AA, Gonçalves JT, Bloyd CW, Li H, Fernandes S, Quang D, Johnston S, Parylak SL, Jin X, Gage FH (2018) An in vivo model of functional and vascularized human brain organoids. Nat Biotechnol 36:432-441.

Marchetto MC, Carromeu C, Acab A, Yu D, Yeo GW, Mu Y, Chen G, Gage FH, Muotri AR (2010) A model for neural development and treatment of Rett syndrome using human induced pluripotent stem cells. Cell 143: 527-539.

Mariani J, Coppola G, Zhang P, Abyzov A, Provini L, Tomasini L, Amenduni M, Szekely A, Palejev D, Wilson M, Gerstein M, Grigorenko EL, Chawarska K, Pelphrey KA, Howe JR, Vaccarino FM (2015) FOXG1-dependent dysregulation of GABA/glutamate neuron differentiation in autism spectrum disorders. Cell 162:375-390.

Maroof AM, Keros S, Tyson JA, Ying SW, Ganat YM, Merkle FT, Liu B, Goulburn A, Stanley EG, Elefanty AG, Widmer HR, Eggan K, Goldstein PA, Anderson SA, Studer L (2013) Directed differentiation and functional maturation of cortical interneurons from human embryonic stem cells. Cell Stem Cell 12:559-572.

Marshall CR, Howrigan DP, Merico D, Thiruvahindrapuram B, Wu W, Greer DS, Antaki D, Shetty A, Holmans PA, Pinto D, Gujral M, Brandler WM, Malhotra D, Wang Z, Fajarado KV, Maile MS, Ripke S, Agartz I, Albus M, Alexander M, et al. (2017) Contribution of copy number variants to schizophrenia from a genome-wide study of 41,321 subjects. Nat Genet 49:27-35.

Matsunami N, Hadley D, Hensel CH, Christensen GB, Kim C, Frackelton E, Thomas K, da Silva RP, Stevens J, Baird L, Otterud B, Ho K, Varvil T, Leppert T, Lambert CG, Leppert M, Hakonarson H (2013) Identification of rare recurrent copy number variants in high-risk autism families and their prevalence in a large ASD population. PLoS One 8:e52239.

McPhie DL, Nehme R, Ravichandran C, Babb SM, Ghosh SD, Staskus A, Kalinowski A, Kaur R, Douvaras P, Du F, Ongur D, Fossati V, Eggan K, Cohen BM (2018) Oligodendrocyte differentiation of induced pluripotent stem cells derived from subjects with schizophrenias implicate abnormalities in development. Transl Psychiatry 8:230.

Meijer M, Rehbach K, Brunner JW, Classen JA, Lammertse HC, van Linge LA, Schut D, Krutenko T, Hebisch M, Cornelisse LN, Sullivan PF, Peitz M, Toonen RF, Brüstle O, Verhage M (2019) A single-cell model for synaptic transmission and plasticity in human iPSC-derived neurons. Cell Rep 27:2199-2211.e6.

Mertens J, Wang QW, Kim Y, Yu DX, Pham S, Yang B, Zheng Y, Diffenderfer KE, Zhang J, Soltani S, Eames T, Schafer ST, Boyer L, Marchetto MC, Nurnberger JI, Calabrese JR, Ødegaard KJ, McCarthy MJ, Zandi PP, Alda M, et al. (2015a) Differential responses to lithium in hyperexcitable neurons from patients with bipolar disorder. Nature 527:95-99.

Mertens J, Paquola AC, Ku M, Hatch E, Böhnke L, Ladjevardi S, McGrath S, Campbell B, Lee H, Herdy JR, Gonçalves JT, Toda T, Kim Y, Winkler J, Yao J, Hetzer MW, Gage FH (2015b) Directly reprogrammed human neurons retain aging-associated transcriptomic signatures and reveal agerelated nucleocytoplasmic defects. Cell Stem Cell 17:705-718.

Miranda C, Fernandes T, Diogo M, Cabral J (2018) Towards multiorganoid systems for drug screening applications. Bioengineering 5:49.

Moffat JG, Vincent F, Lee JA, Eder J, Prunotto M (2017) Opportunities and challenges in phenotypic drug discovery: an industry perspective. Nat Rev Drug Discov 16:531-543.

Muffat J, Li Y, Yuan B, Mitalipova M, Omer A, Corcoran S, Bakiasi G, Tsai LH, Aubourg P, Ransohoff RM, Jaenisch R (2016) Efficient derivation of microglia-like cells from human pluripotent stem cells. Nat Med 22: $1358-1367$.

Muffat J, Li Y, Omer A, Durbin A, Bosch I, Bakiasi G, Richards E, Meyer A, Gehrke L, Jaenisch R (2018) Human induced pluripotent stem cellderived glial cells and neural progenitors display divergent responses to Zika and dengue infections. Proc Natl Acad Sci U S A 115:7117-7122.

Nicholas CR, Chen J, Tang Y, Southwell DG, Chalmers N, Vogt D, Arnold CM, Chen YJ, Stanley EG, Elefanty AG, Sasai Y, Alvarez-Buylla A, Rubenstein JL, Kriegstein AR (2013) Functional maturation of hPSC-derived forebrain interneurons requires an extended timeline and mimics human neural development. Cell Stem Cell 12:573-586.

Pak C, Danko T, Zhang Y, Aoto J, Anderson G, Maxeiner S, Yi F, Wernig M, Südhof TC (2015) Human neuropsychiatric disease modeling using conditional deletion reveals synaptic transmission defects caused by heterozygous mutations in NRXN1. Cell Stem Cell 17:316-328.

Pang ZP, Yang N, Vierbuchen T, Ostermeier A, Fuentes DR, Yang TQ, Citri A, Sebastiano V, Marro S, Südhof TC, Wernig M (2011) Induction of human neuronal cells by defined transcription factors. Nature 476:220-223.

Pardiñas AF, Holmans P, Pocklington AJ, Escott-Price V, Ripke S, Carrera N, Legge SE, Bishop S, Cameron D, Hamshere ML, Han J, Hubbard L, Lynham A, Mantripragada K, Rees E, MacCabe JH, McCarroll SA, Baune BT, Breen G, Byrne EM, et al. (2018) Common schizophrenia alleles are enriched in mutation-intolerant genes and in regions under strong background selection. Nat Genet 50:381-389.

Pasca AM, Sloan SA, Clarke LE, Tian Y, Makinson CD, Huber N, Kim CH, Park JY, O’Rourke NA, Nguyen KD, Smith SJ, Huguenard JR, Geschwind DH, Barres BA, Pasca SP (2015) Functional cortical neurons and astro- 
cytes from human pluripotent stem cells in 3D culture. Nat Methods 12:671-678.

Paull D, Sevilla A, Zhou H, Hahn AK, Kim H, Napolitano C, Tsankov A, Shang L, Krumholz K, Jagadeesan P, Woodard CM, Sun B, Vilboux T, Zimmer M, Forero E, Moroziewicz DN, Martinez H, Malicdan MC, Weiss KA, Vensand LB, et al. (2015) Automated, high-throughput derivation, characterization and differentiation of induced pluripotent stem cells. Nat Methods 12:885-892.

Pawlowski M, Ortmann D, Bertero A, Tavares JM, Pedersen RA, Vallier L, Kotter MR (2017) Inducible and deterministic forward programming of human pluripotent stem cells into neurons, skeletal myocytes, and oligodendrocytes. Stem Cell Reports 8:803-812.

Powell SK, Gregory J, Akbarian S, Brennand KJ (2017) Molecular and cellular neuroscience application of CRISPR/Cas9 to the study of brain development and neuropsychiatric disease. Mol Cell Neurosci 82:157-166.

Pulecio J, Verma N, Mejía-Ramírez E, Huangfu D, Raya A (2017) CRISPR/ Cas9-based engineering of the epigenome. Cell Stem Cell 21:431-447.

Puttonen KA, Ruponen M, Naumenko N, Hovatta OH, Tavi P, Koistinaho J (2015) Generation of functional neuromuscular junctions from human pluripotent stem cell lines. Front Cell Neurosci 9:473.

Quadrato G, Nguyen T, Macosko EZ, Sherwood JL, Min Yang S, Berger DR, Maria N, Scholvin J, Goldman M, Kinney JP, Boyden ES, Lichtman JW, Williams ZM, McCarroll SA, Arlotta P (2017) Cell diversity and network dynamics in photosensitive human brain organoids. Nature 545: $48-53$.

Rajarajan P, Borrman T, Liao W, Schrode N, Flaherty E, Casiño C, Powell S, Yashaswini C, LaMarca EA, Kassim B, Javidfar B, Espeso-Gil S, Li A, Won H, Geschwind DH, Ho SM, MacDonald M, Hoffman GE, Roussos P, Zhang B, et al. (2018) Neuron-specific signatures in the chromosomal connectome associated with schizophrenia risk. Science 362:eaat4311.

Readhead B, Hartley BJ, Eastwood BJ, Collier DA, Evans D, Farias R, He C, Hoffman G, Sklar P, Dudley JT, Schadt EE, Savic R, Brennand KJ (2018) Expression-based drug screening of neural progenitor cells from individuals with schizophrenia. Nat Commun 9:4412.

Rhee HJ, Shaib AH, Rehbach K, Lee C, Seif P, Thomas C, Gideons E, Guenther A, Krutenko T, Hebisch M, Peitz M, Brose N, Brüstle O, Rhee JS (2019) An autaptic culture system for standardized analyses of iPSC-derived human neurons. Cell Rep 27:2212-2228.e7.

Roussos P, Mitchell AC, Voloudakis G, Fullard JF, Pothula VM, Tsang J, Stahl EA, Georgakopoulos A, Ruderfer DM, Charney A, Okada Y, Siminovitch KA, Worthington J, Padyukov L, Klareskog L, Gregersen PK, Plenge RM, Raychaudhuri S, Fromer M, Purcell SM et al. (2014) A Role for Noncoding Variation in Schizophrenia. Cell Rep 9:1417-1429.

Sanson KR, Hanna RE, Hegde M, Donovan KF, Strand C, Sullender ME, Vaimberg EW, Goodale A, Root DE, Piccioni F, Doench JG (2018) Optimized libraries for CRISPR-Cas9 genetic screens with multiple modalities. Nat Commun 9:5416.

Sanz E, Yang L, Su T, Morris DR, McKnight GS, Amieux PS (2009) Celltype-specific isolation of ribosome-associated mRNA from complex tissues. Proc Natl Acad Sci U S A 106:13939-13944.

Schizophrenia Working Group of the Psychiatric Genomics Consortium (2014) Biological insights from 108 schizophrenia-associated genetic loci. Nature 511:421-427.

Schlaeger TM, Daheron L, Brickler TR, Entwisle S, Chan K, Cianci A, DeVine A, Ettenger A, Fitzgerald K, Godfrey M, Gupta D, McPherson J, Malwadkar P, Gupta M, Bell B, Doi A, Jung N, Li X, Lynes MS, Brookes E, et al. (2015) A comparison of non-integrating reprogramming methods. Nat Biotechnol 33:58-63.

Schrode N, Ho SM, Yamamuro K, Dobbyn A, Huckins L, Matos MR, Cheng E, Deans PJ, Flaherty E, Barretto N, Topol A, Alganem K, Abadali S, Gregory J, Hoelzli E, Phatnani H, Singh V, Girish D, Aronow B, Mccullumsmith R, et al. (2019) Synergistic effects of common schizophrenia risk variants. Nat Genet 51:1475-1485.

Schwartzentruber J, Foskolou S, Kilpinen H, Rodrigues J, Alasoo K, Knights AJ, Patel M, Goncalves A, Ferreira R, Benn CL, Wilbrey A, Bictash M, Impey E, Cao L, Lainez S, Loucif AJ, Whiting PJ, Whiting PJ, Gutteridge A, Gaffney DJ, et al. (2018) Molecular and functional variation in iPSCderived sensory neurons. Nat Genet 50:54-61.

Sellgren CM, Sheridan SD, Gracias J, Xuan D, Fu T, Perlis RH (2017) Patient-specific models of microglia-mediated engulfment of synapses and neural progenitors. Mol Psychiatry 22:170-177.

Sellgren CM, Gracias J, Watmuff B, Biag JD, Thanos JM, Whittredge PB, Fu T,
Worringer K, Brown HE, Wang J, Kaykas A, Karmacharya R, Goold CP, Sheridan SD, Perlis RH (2019) Increased synapse elimination by microglia in schizophrenia patient-derived models of synaptic pruning. Nat Neurosci 22:374-385.

Shao Z, Noh H, Bin Kim W, Ni P, Nguyen C, Cote SE, Noyes E, Zhao J, Parsons T, Park JM, Zheng K, Park JJ, Coyle JT, Weinberger DR, Straub RE, Berman KF, Apud J, Ongur D, Cohen BM, McPhie DL, et al. (2019) Dysregulated protocadherin-pathway activity as an intrinsic defect in induced pluripotent stem cell-derived cortical interneurons from subjects with schizophrenia. Nat Neurosci 22:229-242.

Shi Y, Lin S, Staats KA, Li Y, Chang WH, Hung ST, Hendricks E, Linares GR, Wang Y, Son EY, Wen X, Kisler K, Wilkinson B, Menendez L, Sugawara T, Woolwine P, Huang M, Cowan MJ, Ge B, Koutsodendris N, et al. (2018) Haploinsufficiency leads to neurodegeneration in C9ORF72 ALS/FTD human induced motor neurons. Nat Med 24:313-325.

Shi Y, Kirwan P, Livesey FJ (2012) Directed differentiation of human pluripotent stem cells to cerebral cortex neurons and neural networks. Nat Protoc 7:1836-1846.

Silva MC, Haggarty SJ (2019) Human pluripotent stem cell-derived models and drug screening in CNS precision medicine. Ann N Y Acad Sci Advance online publication. Retrieved Mar 15, 2019. doi: 10.1111/nyas. 14012.

Singh D, Mallon J, Poddar A, Wang Y, Tippana R, Yang O, Bailey S, Ha T (2018) Real-time observation of DNA target interrogation and product release by the RNA-guided endonuclease CRISPR Cpf1 (Cas12a). Proc Natl Acad Sci U S A 115:5444-5449.

Sittig LJ, Carbonetto P, Engel KA, Krauss KS, Barrios-Camacho CM, Palmer AA (2016) Genetic background limits generalizability of genotype-phenotype relationships. Neuron 91:1253-1259.

Skene NG, Bryois J, Bakken TE, Breen G, Crowley JJ, Gaspar HA, GiustiRodriguez P, Hodge RD, Miller JA, Muñoz-Manchado AB, O’Donovan MC, Owen MJ, Pardiñas AF, Ryge J, Walters JT, Linnarsson S, Lein ES, Sullivan PF, Hjerling-Leffler J (2018) Genetic identification of brain cell types underlying schizophrenia. Nat Genet 50:825-833.

Sloan SA, Andersen J, Pasca AM, Birey F, Pasca SP (2018) Generation and assembly of human brain region-specific three-dimensional cultures. Nat Protoc 13:2062-2085.

Srikanth P, Han K, Callahan DG, Makovkina E, Muratore CR, Lalli MA, Zhou H, Boyd JD, Kosik KS, Selkoe DJ, Young-Pearse TL (2015) Genomic DISC1 disruption in hiPSCs alters wnt signaling and neural cell fate. Cell Rep 12:1414-1429.

Stern S, Santos R, Marchetto MC, Mendes AP, Rouleau GA, Biesmans S, Wang QW, Yao J, Charnay P, Bang AG, Alda M, Gage FH (2018) Neurons derived from patients with bipolar disorder divide into intrinsically different sub-populations of neurons, predicting the patients' responsiveness to lithium. Mol Psychiatry 23:1453-1465.

Sullivan PF, Geschwind DH (2019) Defining the genetic, genomic, cellular, and diagnostic architectures of psychiatric disorders. Cell 177:162-183.

Sun AX, Yuan Q, Tan S, Xiao Y, Wang D, Khoo AT, Sani L, Tran HD, Kim P, Chiew YS, Lee KJ, Yen YC, Ng HH, Lim B, Je HS (2016) Direct induction and functional maturation of forebrain GABAergic neurons from human pluripotent stem cells. Cell Rep 16:1929-1941.

Tai DJ, Ragavendran A, Manavalan P, Stortchevoi A, Seabra CM, Erdin S, Collins RL, Blumenthal I, Chen X, Shen Y, Sahin M, Zhang C, Lee C, Gusella JF, Talkowski ME (2016) Engineering microdeletions and microduplications by targeting segmental duplications with CRISPR. Nat Neurosci 19:517-522.

Tang H, Hammack C, Ogden SC, Wen Z, Qian X, Li Y, Yao B, Shin J, Zhang F, Lee EM, Christian KM, Didier RA, Jin P, Song H, Ming GL (2016) Zika virus infects human cortical neural progenitors and attenuates their growth. Cell Stem Cell 18:587-590.

Tcw J, Wang M, Pimenova AA, Bowles KR, Hartley BJ, Lacin E, Machlovi SI, Abdelaal R, Karch CM, Phatnani H, Slesinger PA, Zhang B, Goate AM, Brennand KJ (2017) An efficient platform for astrocyte differentiation from human induced pluripotent stem cells. Stem Cell Reports 9:600614.

Theka I, Caiazzo M, Dvoretskova E, Leo D, Ungaro F, Curreli S, Managò F, Dell'Anno MT, Pezzoli G, Gainetdinov RR, Dityatev A, Broccoli V (2013) Rapid generation of functional dopaminergic neurons from human induced pluripotent stem cells through a single-step procedure using cell lineage transcription factors. Stem Cells Transl Med 2:473-479.

Thompson PM, Stein JL, Medland SE, Hibar DP, Vasquez AA, Renteria ME, 
Toro R, Jahanshad N, Schumann G, Franke B, Wright MJ, Martin NG, Agartz I, Alda M, Alhusaini S, Almasy L, Almeida J, Alpert K, Andreasen NC, Andreassen OA, et al. (2014) The ENIGMA consortium: large-scale collaborative analyses of neuroimaging and genetic data. Brain Imaging Behav 8:153-182.

Tian R, Gachechiladze MA, Ludwig CH, Laurie MT, Hong JY, Nathaniel D, Prabhu AV, Fernandopulle MS, Patel R, Abshari M, Ward ME, Kampmann M (2019) CRISPR interference-based platform for multimodal genetic screens in human iPSC-derived neurons. Neuron 104:239-255.e12.

Topol A, Zhu S, Hartley BJ, English J, Hauberg ME, Tran N, Rittenhouse CA, Simone A, Ruderfer DM, Johnson J, Readhead B, Hadas Y, Gochman PA, Wang YC, Shah H, Cagney G, Rapoport J, Gage FH, Dudley JT, Sklar P, et al. (2016) Dysregulation of miRNA-9 in a subset of schizophrenia patient-derived neural progenitor cells. Cell Rep 15:1024-1036.

Tsunemoto R, Lee S, Szucs A, Chubukov P, Sokolova I, Blanchard JW, Eade KT, Bruggemann J, Wu C, Torkamani A, Sanna PP, Baldwin KK (2018) Diverse reprogramming codes for neuronal identity. Nature 557:375380.

Vadodaria KC, Mertens J, Paquola A, Bardy C, Li X, Jappelli R, Fung L, Marchetto MC, Hamm M, Gorris M, Koch P, Gage FH (2016) Generation of functional human serotonergic neurons from fibroblasts. Mol Psychiatry 21:49-61.

van der Kant R, Langness VF, Herrera CM, Williams DA, Fong LK, Leestemaker Y, Steenvoorden E, Rynearson KD, Brouwers JF, Helms JB, Ovaa H, Giera M, Wagner SL, Bang AG, Goldstein LS (2019) Cholesterol metabolism is a druggable axis that independently regulates tau and amyloid- $\beta$ in iPSC-derived Alzheimer's disease neurons. Cell Stem Cell 24:363-375.e9.

Vatine GD, Al-Ahmad A, Barriga BK, Svendsen S, Salim A, Garcia L, Garcia VJ, Ho R, Yucer N, Qian T, Lim RG, Wu J, Thompson LM, Spivia WR, Chen Z, Van Eyk J, Palecek SP, Refetoff S, Shusta EV, Svendsen CN (2017) Modeling psychomotor retardation using iPSCs from MCT8deficient patients indicates a prominent role for the blood-brain barrier. Cell Stem Cell 20:831-843.e5.

Velasco S, Kedaigle AJ, Simmons SK, Nash A, Rocha M, Quadrato G, Paulsen B, Nguyen L, Adiconis X, Regev A, Levin JZ, Arlotta P (2019) Individual brain organoids reproducibly form cell diversity of the human cerebral cortex. Nature 570:523-527.

Vierbuchen T, Ostermeier A, Pang ZP, Kokubu Y, Südhof TC, Wernig M (2010) Direct conversion of fibroblasts to functional neurons by defined factors. Nature 463:1035-1041.

Vora S, Tuttle M, Cheng J, Church G (2016) Next stop for the CRISPR revolution: RNA-guided epigenetic regulators. FEBS J 283:3181-3193.

Wang C, Ward ME, Chen R, Liu K, Tracy TE, Chen X, Xie M, Sohn PD, Ludwig C, Meyer-Franke A, Karch CM, Ding S, Gan L (2017) Scalable production of iPSC-derived human neurons to identify tau-lowering compounds by high-content screening. Stem Cell Reports 9:1221-1233.

Wang H, Xu X, Nguyen CM, Liu Y, Gao Y, Lin X, Daley T, Kipniss NH, La Russa M, Qi LS (2018) CRISPR-mediated programmable 3D genome positioning and nuclear organization. Cell 175:1405-1417.e14.

Wang S, Bates J, Li X, Schanz S, Chandler-Militello D, Levine C, Maherali N, Studer L, Hochedlinger K, Windrem M, Goldman SA (2013) Human iPSC-derived oligodendrocyte progenitor cells can myelinate and rescue a mouse model of congenital hypomyelination. Cell Stem Cell 12:252-264.

Wen X, Tan W, Westergard T, Krishnamurthy K, Markandaiah SS, Shi Y, Lin S, Shneider NA, Monaghan J, Pandey UB, Pasinelli P, Ichida JK, Trotti D
(2014) Antisense proline-arginine RAN dipeptides sense antisense regulation. Neuron 84:1213-1225.

Wen Z, Nguyen HN, Guo Z, Lalli MA, Wang X, Su Y, Kim NS, Yoon KJ, Shin J, Zhang C, Makri G, Nauen D, Yu H, Guzman E, Chiang CH, Yoritomo N, Kaibuchi K, Zou J, Christian KM, Cheng L, et al. (2014) Synaptic dysregulation in a human iPS cell model of mental disorders. Nat Lett 515:1-5.

Windrem MS, Osipovitch M, Liu Z, Findling RL, Tesar PJ, Goldman SA, Windrem MS, Osipovitch M, Liu Z, Bates J, Chandler-Militello D, Zou L, Findling RL, Tesar PJ, Goldman SA (2017) Human iPSC glial mouse chimeras reveal glial contributions to schizophrenia. Stem Cell 21:195208.e6.

Xiang Y, Tanaka Y, Patterson B, Kang YJ, Govindaiah G, Roselaar N, Cakir B, Kim KY, Lombroso AP, Hwang SM, Zhong M, Stanley EG, Elefanty AG, Naegele JR, Lee SH, Weissman SM, Park IH (2017) Fusion of regionally specified hPSC-derived organoids models human brain development and interneuron migration. Cell Stem Cell 21:383-398.e7.

Xiang Y, Tanaka Y, Cakir B, Patterson B, Kim KY, Sun P, Kang YJ, Zhong M, Liu X, Patra P, Lee SH, Weissman SM, Park IH (2019) hESC-derived thalamic organoids form reciprocal projections when fused with cortical organoids. Cell Stem Cell 24:487-497.e7.

Yang N, Chanda S, Marro S, Ng YH, Janas JA, Haag D, Ang CE, Tang Y, Flores Q, Mall M, Wapinski O, Li M, Ahlenius H, Rubenstein JL, Chang HY, Buylla AA, Südhof TC, Wernig M (2017) Generation of pure GABAergic neurons by transcription factor programming. Nat Methods 14:621628.

Yang YM, Gupta SK, Kim KJ, Powers BE, Cerqueira A, Wainger BJ, Ngo HD, Rosowski KA, Schein PA, Ackeifi CA, Arvanites AC, Davidow LS, Woolf CJ, Rubin LL (2013) A small molecule screen in stem-cell-derived motor neurons identifies a kinase inhibitor as a candidate therapeutic for ALS. Cell Stem Cell 12:713-726.

Yi F, Danko T, Botelho SC, Patzke C, Pak C, Wernig M, Südhof TC (2016) Autism-associated SHANK3 haploinsufficiency causes Ih channelopathy in human neurons. Science 352:aaf2669.

Yu DX, Di Giorgio FP, Yao J, Marchetto MC, Brennand K, Wright R, Mei A, McHenry L, Lisuk D, Grasmick JM, Silberman P, Silberman G, Jappelli R, Gage FH (2014) Modeling hippocampal neurogenesis using human pluripotent stem cells. Stem Cell Reports 2:295-310.

Zaslavsky K, Zhang WB, McCready FP, Rodrigues DC, Deneault E, Loo C, Zhao M, Ross PJ, El Hajjar J, Romm A, Thompson T, Piekna A, Wei W, Wang Z, Khattak S, Mufteev M, Pasceri P, Scherer SW, Salter MW, Ellis J (2019) SHANK2 mutations associated with autism spectrum disorder cause hyperconnectivity of human neurons. Nat Neurosci 22:556-564.

Zetsche B, Gootenberg JS, Abudayyeh OO, Slaymaker IM, Makarova KS, Essletzbichler P, Volz SE, Joung J, van der Oost J, Regev A, Koonin EV, Zhang F (2015) Cpf1 is a single RNA-guided endonuclease of a class 2 CRISPR-cas system. Cell 163:759-771.

Zhang P, Xia N, Reijo Pera RA (2014) Directed dopaminergic neuron differentiation from human pluripotent stem cells. J Vis Exp 91:51737.

Zhang Y, Pak C, Han Y, Ahlenius H, Zhang Z, Chanda S, Marro S, Patzke C, Acuna C, Covy J, Xu W, Yang N, Danko T, Chen L, Wernig M, Südhof TC (2013) Rapid single-step induction of functional neurons from human pluripotent stem cells. Neuron 78:785-798.

Zhou T, Tan L, Cederquist GY, Fan Y, Hartley BJ, Mukherjee S, Tomishima M, Brennand KJ, Zhang Q, Schwartz RE, Evans T, Studer L, Chen S (2017) High-content screening in hPSC-neural progenitors identifies drug candidates that inhibit Zika virus infection in fetal-like organoids and adult brain. Cell Stem Cell 21:274-283.e5. 